\title{
Learning Present Continuous Tense Made Easy through "Son, Mummy and the -ing Cat" Module
}

\author{
Mohamad Hafizuddin Ma'mor, Hamidah Yamat* \\ Faculty of Education, Universiti Kebangsaan Malaysia, Bangi, Malaysia \\ Email: ^hamidah_yamat@ukm.edu.my
}

How to cite this paper: Ma'mor, M. H., \& Yamat, H. (2019). Learning Present Continuous Tense Made Easy through "Son, Mummy and the -ing Cat" Module. Creative Education, 10, 2831-2839. https://doi.org/10.4236/ce.2019.1012209

Received: October 21, 2019

Accepted: November 26, 2019

Published: November 29, 2019

Copyright ( 2019 by author(s) and Scientific Research Publishing Inc. This work is licensed under the Creative Commons Attribution International License (CC BY 4.0).

http://creativecommons.org/licenses/by/4.0/ (c) (i) Open Access

\begin{abstract}
Learning the grammar, particularly tenses of English language may be difficult or confusing to many second or foreign language learners whose mother tongue does not have a complex grammar system, such as Malay Language. This raises problems in constructing grammatically correct sentences; both in spoken and written work. Hence, there is a need to find means that would be easy and fun to help children learn the grammar of English. This paper presents and discusses a quasi-experimental study that aimed to test the effectiveness of an innovative module developed and named "Son, Mummy and the -ing cat" to aid students in constructing correct present continuous sentences. It integrates elements of storytelling, puppetry, role-play and word cards as an in-class intervention activity. 58 Year Six (age 12) pupils experienced using the module for 13 days and their writing performance was assessed in the pre-and post-tests of their sentence-production. Findings of the paired samples t-test show a difference of means between the two tests. The students constructed more and higher instances of correct present continuous tense sentences after the use of the module. This further implies that learning a concept, although complex and confusing as the English grammar, can be enhanced with creative teaching aids.
\end{abstract}

\section{Keywords}

Module, Present Continuous Tense, Learning, Teaching Aids, Grammar

\section{Introduction}

Many teachers of English language face difficulty in teaching grammar as most students are not able to master the verb tense system of the language (Larsen-Freeman, Kuehn, \& Haccius, 2002). This may be due to the different grammar systems of different languages. For instance, English and Arabic display 
huge grammatical differences, where some elements in English grammar are not even found in Arabic. Hence, Arab students face difficulties understanding these elements, particularly the usage and function of the verbs be, do, and have and applying the present perfect tense correctly (Ebtesam Basaeed, 2013). Meanwhile, in another language such as the Malay language, descriptors are added to indicate whether the action is in the present tense (sedang), past (telah) or future (akan) and the verbs remain in the root form regardless of the number of person(s) doing the action. However, in English language, changes are made on the verbs to indicate when the action takes place (present/past/future/is completed, or is still in progress) and the person (singular) or people (plural) doing the action. It is therefore not a surprise when findings of a study in Malaysia show that despite having gone through six years of learning English in school environment, the learners are still having difficulty in using correct English grammar in their writings (Maros et al., 2007). Similar finding was also gathered from a study on gifted learners who were found facing difficulty in applying grammatical rules in discourse manner (Md Yunus et al., 2013). Even at tertiary level, Yusob (2018) found that experienced lecturers too faced difficulty in teaching and explaining about English grammar to the students. Apart from the linguistics feature of English language, exposure to the language and opportunity to use it are two of the social factors that may encourage or discourage students to learn and use the language (Yamat, 2019). In addition, geographical aspect also contributes to the learning process. For instance, students in rural areas such as the context of this study may not receive exposure to the language and opportunity to use it as much as students in urban areas. The need to learn and use the language too may not be as significant as that for children in the urban areas. Moreover, the absence of technological advancements might deaccelerate their language learning as Singh, Yamat, \& Wahi (2018: pp. 2133-2134) find that the lack of technological equipment and resources acts as a deterrent for teachers to use technology in their teaching and it surprising that even beginning teachers, who are supposedly more knowledgeable, are reluctant to adopt technology in their classrooms. Thus, these rural areas' pupils are left with their teachers and the readily-available materials and do not have the privilege of having the technological-equipped education such as mobile learning and digital classrooms. Even though learners who learn English as a second language have positive attitude towards mobile learning (Hashim, Yunus, \& Embi, 2016: p. 1151), this is not the case for these rural areas' pupils.

Despite the complexity and difficulty to teach and learn English or the little exposure and opportunity to use the language or the need to learn and use the language, English remains a compulsory subject to be taught and learnt for all school going children in Malaysia. Evidence of the decline in English language proficiency and its literacy attainment among Malaysian learners have been investigated quite extensively (Che Musa, Koo, \& Hazman, 2012). Hence, there is a need to find ways that could enhance the learning of English grammar. Mas Rosli et al. (2016) believe that language games have become a powerful tool as a 
platform which cater for different types of learners. Games also encourage learners to the extent where the lesson captivates their attention and enhances their level of confidence to participate actively in the lessons as the result of decrease in their anxiety. In addition, language games help students to direct their own learning (self-directed learning). Hence, this paper presents and discusses a study on the effectiveness of the "Son, Mummy And The -Ing Cat" module developed to help students learn the continuous tense of English language. This section is followed by a brief relevant literature on the tenses in English and the use of games in language teaching and learning. A description of the module and its implementation is then presented to set the purpose and context of the study; prior to the presentation and discussion of the study. This article concludes with the implications of the study.

\section{Literature Review}

\subsection{Tenses Markers in English}

Manucheri (1974) also focused on the learners of English second language's struggle in term of present continuous and simple present tense form. In Farsi, the items "now" and "everyday" appoint the proper time thus it doesn't affect verbs form to signal time reference. The same dilemma encountered by most if Iban native speakers in Sarawak Malaysia as this rule didn't exist in their language system. For instance; "maya", "benung" and some other words represented time reference which no effect towards the verbs had used in the sentences. Azman Shah et al. (2016) added that progressive form has become one of the major problems for Iban students as in Iban language, some words are used in sentences to indicate the continuous actions. According to Steinmayer (1999), Iban language didn't bother about progressive form much as it has its own way of expressing time references. For instance; "di-kelari' which "di" clearly indicates that the action has been going for a while. In addition, some adverbs or phrases also functioned as a sense of imperfect. This explains how English language concentrates on the sense of time and the relation between the times of action the verbs while Iban language states clearly without changing verbs form.

\subsection{The Use of Games in Language Teaching and Learning}

According to Gredler (2004), using game in learning might be useful; 1) to practice acquired knowledge and skills, 2) reckon the notch in the knowledge skill, 3) supply concise review and 4) produce fresh relation between concept and principle. Connolly, Stansfield \& Hainey (2011) argue that game-based learning had slight fundamental part with promoting educational learning for the past few years. Prensky (2001) in his study proved that the sample regarded earning through game was considered as "hard fun". He was also surprised as even the weakest learners engaged adeptly in the game lesson with the strong English language components. Some educators are still perceived educational game as useful due to its' elements; drilling and practice. However, gaming environment 
was something which is way beyond and complex. As some parts of speech in English are hard to teach, gaming environment provides a useful roundabout path for the learners to learn them in better way.

\section{Methodology}

The main objective of the study was to assess the effects of using the "son, mummy and -ing cat" module. By using this module, the students were expected to improve their construction of progressive sentences. This module serves as a new platform for participants to improve their understanding. It is believed that learners need more exposure of the target language input. There are three main sources for effective learning which are materials, other leaners and the teachers (Andrews, 1999). Thus, by using materials, perhaps learners are able to grasp the rules of grammar in easier way. Referring to the objective above, the research question that can be derived for this study is:

How does "son, mummy, and ing cat" teaching material effect pupils' production of present continuous sentences?

\subsection{Research Design and Sampling}

This study employed a quasi-experimental research and the data were analysed through a quantitative method. Due to limited samples, a quasi-experimental research design was chosen when it is not possible to randomize individuals or groups to treatment and control group (White \& Sabarwal, 2014). Also access to the samples was another justification for employing a convenient sampling method. A total of 58 Year Six pupils aged twelve from three schools in different districts of Sarawak took part in the study. All three schools are classified as rural area schools which consisted of various ethnic groups; namely, Iban, Melanau and Sarawakian Malay. Their first language is their ethnic mother tongue while English is their third language. Thus, the pupils have limited exposure to English language outside of the classroom. Their performance in the subject too indicate that they are intermediate and weak users of English.

\subsection{Data Collection Technique and Procedure}

The "son, mummy and the -ing cat" teaching module created to ease students' learning and understanding of the present continuous tense. The "son" signifies auxiliary verbs, "mummy" signifies the main verb while "cat" signifies the -ing participle. The module was based on a simple analogy on which the "mummy" (main verb) could go out alone thus forming the concept of a complete sentence with an object and a main verb (e.g. They cry). There is a condition for the "son" (auxiliary verb) to tag along where they must bring the "cat" (-ing participle) thus forming a complete present continuous tense sentence (They are crying). Apre and post-test was employed to compare the children's production of present continuous sentences before and after using the module. The samples were given a written test (pre-test) where they were required to generate sen- 
tences based on a given picture stimulus taken from the actual English Section A question in a Ujian Penilaian Sekolah Rendah (UPSR) which is a standardised national examination (see Appendix). No discussion or guidance was given throughout the session. After the pre-test, pupils' sentences were analysed and their sentences were categorized into a few categories which are the existence of present continuous tense (correct usage or wrong usage), sentences without present continuous tense and total number of sentences. The treatment sessions were carried out for 13 days where the module was utilized for the first $10 \mathrm{mi}$ nutes of every English lesson during school days.

The children were introduced to short stories based on the aforementioned analogy through a puppet show using the module. Mini socks puppets representing the characters in the story were prepared beforehand. Once the pupils were able to retell the story, then the students were asked to have a closer experience to the story. A total of 174 masks which consists of 58 masks for each character were produced. Through these masks, the pupils acted out and did a role-play based on the story. Word cards were prepared to aid children's sentence building. In addition, various games and activities such as "Partner Hunting" and "Sentence Building" were conducted through this module. It is believed that teacher's effective teaching strategies will allow the students to grasp better in learning English as well as facilitate students' interest in the learning process (Amjah, 2014) The children had to construct short sentences and write them on a manila card. Mini presentations by the group members were done and the teacher corrected any mistakes. Through these activities, the children learnt from one another through a game approach.

\subsection{Data Analysis}

Content analysis was done on the students' writing in the pre and post-tests. The frequencies for all sentence categories were calculated and presented in percentage. Comparison from pre and post-test data was done to measure the effects of the "son, mummy and the -ing cat" teaching module on the pupils' sentence production of present continuous tense. All data was recorded in the table as Table 1.

Table 1. Descriptive analysis of pre-test \& post-test.

\begin{tabular}{ccc}
\hline \multicolumn{1}{c}{ Pre-test } & Aspect & Post-test \\
\hline 11 & Average written sentences in test & 11 \\
607 & Total written sentences \\
305 & Sentences without present continuous tense & 208 \\
302 & Sentences with present continuous tense & 449 \\
$39 \%$ out of 302 & Percentage of sentences with & $8 \%$ out of 449 \\
& wrong use of present continuous tense & \\
$61 \%$ out of $302(184)$ & Percentage of sentences with & $92 \%$ out of $449(413)$ \\
& $\underline{\text { correct use of present continuous tense }}$
\end{tabular}




\section{Findings}

The post-test finding shows 657 sentences were produced; 50 sentences more than in the pre-test although the average number of sentences of each participant is still 11. The increase of the written sentences may be due to increased repeated exposure to sentences with present continuous tense. This is also indicated with the reduced number of sentences without present tense (449 sentences in post-test in comparison to 302 in pre-test). In terms of accuracy in producing sentences with correct use of the present continuous tense, there is an increase of 229 sentences. To further support the effect of the focused teaching material, a statistical analysis which is paired samples T-test was employed to compare the scores within the groups of subjects. It is shown that this study's result is significant $(\mathrm{t}=-7.353, \mathrm{df}=57, p<0.05)$ and it is concluded that there is a difference between the students' correct production of present continuous tense sentences before and after the use of the teaching module. This answers this study's research question as the focused teaching material does have the positive effect in increasing correct present continuous tense sentences of the participants (Table 2).

\subsection{Implications of the Study}

The implications of this study is focused on the pedagogical implications as these implications have the capability to improve the current English teaching and learning situations, especially in the context of rural schools. First, the usage of "Son, Mummy and the 'ing' cat" teaching material could provide another "refreshed" dimension towards teaching a grammar item in daily English lessons. It is widely known that grammar is associated with difficulties among second language users who write in English and the association extends to the colourless process of learning grammar due to the rules memorisation as it is compared to the rules' application (Farooq, Uzair-Ul-Hassan, \& Wahid, 2012: p. 186). To make matters worse, Watcharapunyawong \& Usaha (2013: p. 67) believe that writing could not be more perceivably complicated due to the technological advancement that requires email and others. Hence, the combination of grammar and writing skills might not be a sweet spot for second language or foreign language learners of English. The adoption of another perspective towards teaching grammar item could be the best step to improve the situation so that learners are not satiated with the usual or typical grammar lessons. By having the focused teaching material such as "Son, Mummy and the 'ing' cat" could mask grammar-focused activity to a novel activity that could integrate all English learners

Table 2. T-test.

\begin{tabular}{|c|c|c|c|c|c|c|c|c|}
\hline & \multirow{2}{*}{ mean } & \multirow{2}{*}{$\begin{array}{l}\text { Standard } \\
\text { deviation }\end{array}$} & \multirow{2}{*}{$\begin{array}{l}\text { Standard } \\
\text { error mean }\end{array}$} & \multicolumn{2}{|c|}{$95 \%$ confidence interval of the difference } & \multirow{2}{*}{$\mathrm{t}$} & \multirow{2}{*}{ df } & \multirow{2}{*}{$\begin{array}{c}\text { Sigma } \\
\text { (2-tailed) }\end{array}$} \\
\hline & & & & Lower & Upper & & & \\
\hline Pre-test - post-test & 3.91379 & 4.05352 & 0.53225 & -4.97961 & -2.84797 & -7.353 & 57 & 0.000 \\
\hline
\end{tabular}


in the class to participate and cooperate to generate correct present continuous tense sentences. Additionally, pupils' motivation can be elevated when the material's content is interesting to them (Nath, Mohamad, \& Yamat, 2017: p. 1374), especially when it involves stories and games for young learners.

The next implication is that the researched teaching material could serve as the intervention plan to English teachers when they encounter pupils' errors in present continuous tense sentence constructions. Kaweera (2013: p. 9) describe errors could not be avoided in learning English especially for foreign language purposes. This suits this study's participants well due to the fact that the exposure of English is low in these three schools that are located in rural areas thus producing errors in their writings are inevitable. Manokaran, Ramalingam, \& Adriana (2013: p. 111) add that opportunities that are scarce could be the factor of learners' errors. It is common in this study's three schools that formal schooling provides the main English exposure and it is uncertain whether they have extra English input outside as English usage might not be as much as at school. Hence, learners' errors could not be easily deemphasised. These implications of the "Son, Mummy and -ing cat" material have to be considered for English teachers, trainers and curriculum/material developers in order to further improve English teaching and learning.

\subsection{Conclusion}

The adoption of "Son, Mummy and the '-ing' cat" teaching material can be integrated in English lessons as it can provide a decent effect in improving pupils' mastery of present continuous tense. English teachers are encouraged to adapt this teaching material to fit their pupils, teaching situation and their context so as to assist pupils to master this grammar aspect and add a different prospect in teaching grammar in their English classrooms. There are rooms for teachers to adapt this teaching material to suit their context especially in the storyline, characters, materials and implementations as it could further strengthen the material's effectiveness.

\section{Funding}

This project is supported by the Faculty of Education Research Grant GG-2019-016 and PP-FPEND-2019.

\section{Conflicts of Interest}

The authors declare no conflicts of interest regarding the publication of this paper.

\section{References}

Amjah, D. Y. P. H. (2014). A Study of Teachers' Strategies So Develop Students' Interest towards Learning English as a Second Language. Procedia-Social and Behavioral Sciences, 134, 188-192. https://doi.org/10.1016/j.sbspro.2014.04.238

Andrews, S. (1999). Why Do L2 Teachers Need to "Know about Language"? Teacher Me- 
talinguistic Awareness and Input for Learning. Language and Education, 13, 161-177. http://hub.hku.hk/bitstream/10722/42666/1/50306.pdf?accept=1 https://doi.org/10.1080/09500789908666766

Azman Shah, N. M. F. S., Mamor, M. H., Mas Rosli, M. F., Abdullah, N. A., Yaakub, A. R., Md Yunus, M., \& Mohamad, M. (2016). Investigating Interlingual Influence in Pupils' English Writing: A Case in Sarawak. In ICEISR 2016 (pp. 1574-1594). Banda Aceh: RCS Global Sincere Resources.

Basaeed, E. (2013). An Approach for Teaching English Language Grammar to Arab Young Learners. IOSR Journal of Research \& Method in Education, 1, 20-30. https://doi.org/10.9790/7388-0122030

Che Musa, N., Koo, Y. L., \& Hazman, H. (2012). Exploring English Language Learning and Teaching in Malaysia. GEMA Online ${ }^{m x}$ Journal of Language Studies, 12, 35-51.

Farooq, M. S., Uzair-Ul-Hassan, M., \& Wahid, S. (2012). Opinion of Second Language Learners about Writing Difficulties in English Language. South Asian Studies, 27, 183-194. https://pdfs.semanticscholar.org/951b/3442733b7e154daf2ac374e61338297f7dee.pdf

Hashim, H., Yunus, M. M., \& Embi, M. A. (2016). Pre-University English as Second Language (ESL) Learners' Attitude towards Mobile Learning. Creative Education, 7, 1147-1153. https://doi.org/10.4236/ce.2016.78119

Kaweera, C. (2013). Writing Error: A Review of Interlingual and Intralingual Interference in EFL Context. English Language Teaching, 6, 9-18. https://doi.org/10.5539/elt.v6n7p9 https://files.eric.ed.gov/fulltext/EJ1077017.pdf

Larsen-Freeman, D., Kuehn, T., \& Haccius, M. (2002). Helping Students Make Appropriate English Verb Tense-Aspect Choices. TESOL Journal, 11, 3-9. https://deepblue.lib.umich.edu/bitstream/handle/2027.42/89570/j.1949-3533.2002.tb00 102.x.pdf? sequence $=1$ \&isAllowed $=\mathrm{y}$

Manokaran, J., Ramalingam, C., \& Adriana, K. (2013). A Corpus-Based Study on the Use of Past Tense Auxiliary "Be" in Argumentative Essays of Malaysian ESL Learners. English Language Teaching, 6, 111-119. https://doi.org/10.5539/elt.v6n10p111 http://www.ccsenet.org/journal/index.php/elt/article/download/30166/17873

Manucheri, P. (1974). Explaining Problems of Iranian Students by Comparing English and Farsi Verb Forms. TESOL Quarterly, 8, 137-214. https://doi.org/10.2307/3585541 http://tesol.aua.am/tqd_2000/tqd_2000/Tq_d2000/VOL_08_2.PDF\#page=30

Maros, M., Tan, K. H., \& Salehudin, K. (2007). Interference in Learning English: Grammatical Errors in English Essay Writing among Rural Malay Secondary School Students in Malaysia. https://www.researchgate.net/publication/237782813

Mas Rosli, M. F., Mamor, M. H., Azman Shah, N. M. F. S., Abdullah, N. A., Yaakub, A. R., Md Yunus, M., \& Mohamad, M. (2016). Exploring Effects of Vocabulary Practice Activity through "Word Sniper" Programme: Cases in Sarawak, Malaysia. In ICEISR 2016 (pp. 1351-1371). Banda Aceh: RCS Global Sincere Resources.

Md Yunus, M., Sulaiman, A., Kamarulzaman, M. H., \& Ishak, N. (2013). Language Learning Difficulties among Malaysian Gifted Students. Asian Social Science, 9, 130. https://doi.org/10.5539/ass.v9n15p130

Nath, P. R., Mohamad, M., \& Yamat, H. (2017). The Effects of Movies on the Affective Filter and English Acquisition of Low-Achieving English Learners. Creative Education, 8, 1357-1378. https://doi.org/10.4236/ce.2017.88096

Singh, K. K. K., Yamat, H., \& Wahi, W. (2018). Teachers' Beliefson Technological Fusion in Teaching ESL Students. Creative Education, 9, 2125-2136.

https://doi.org/10.4236/ce.2018.914154 
Steinmayer, O. (1999). Jalai Jako Iban; A Basic Grammar of the Iban Language of Sarawak. Kuching: Klasik Publishing House.

Watcharapunyawong, S., \& Usaha, S. (2013). Thai EFL Students' Writing Errors in Different Text Types: The Interference of the First Language. English Language Teaching, 6, 67-78. http://www.ccsenet.org/journal/index.php/elt/article/download/23044/14794 https://doi.org/10.5539/elt.v6n1p67

Yamat, H. (2019). English Language Competency among Malaysian Children: A Socialisation Process. GJAT, Special Issue, 29-36.

Yusob, K. F. (2018). Challenges of Teaching Grammar at Tertiary Level: Learning from English Lecturers' Insights. e-Academia Journal, 7, 149-158.

http://journale-academiauitmt.uitm.edu.my/v2/index.php/home.html

\section{Appendix}

Picture stimuli

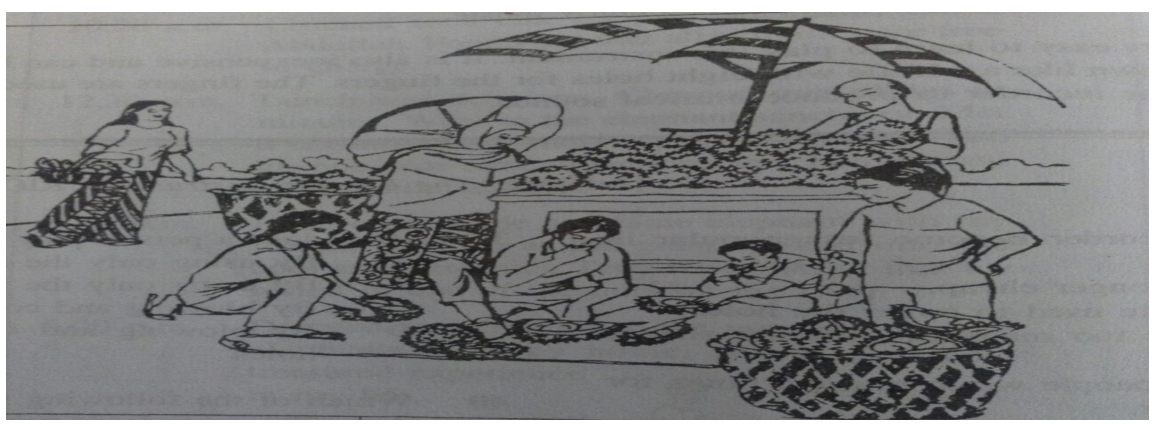

